\title{
Does a greater number of branches improve initial fruit production in camu-camu? A test under different types of plantation and cropping management
}

\author{
Jhon Paul Mathews Delgado ${ }^{1, \star}$, Kaoru Yuyama ${ }^{2}$ and Juan Revilla Cardenas ${ }^{3}$ \\ 1 Instituto Nacional de Pesquisas da Amazônia - INPA, Programa de Pós-graduação em Botânica, Aleixo, Caixa postal - 2223, \\ CEP 69.060-001, Manaus, Brasil \\ 2 INPA, Coordenação de Pesquisas em Ciências Agronômicas, Caixa postal 478, CEP 69.011-970, Manaus, Brasil \\ 3 INPA, Coordenação de Pesquisas em Botânica, Manaus, Brasil
}

Received 9 February 2015 - Accepted 29 September 2015

\begin{abstract}
Introduction. The branches of camu-camu should start sprouting from its base, in order to be positively related to a fruit yield increase. The objective of this study was to consider how plant growth and fruit yield varied according to the plantation type and crop management system. Materials and methods. The growth of the crown and fruit production under different types of plantations originating from cuttings, grafts or seedlings, and seed plantation management: fertilization, pruning and planting different densities, were compared. Results and discussion. Cutting plants formed more branches than those originating from grafting, regardless of the origin of the grafted scion. In seed plantations, zero fertilization and pruning had no effect on the formation of basal branches, but pruning delayed fruit production. Plantations with three plants per hole produced significantly greater numbers of basal branches, but further evaluation is necessary to analyze the effect of this on fruit production. Conclusion. Cutting plantations are technically more desirable than grafting ones because camu-camu trees have better branching from the base. In seed plantations, the selection of plants for their abundant branching from the base is technically feasible. In addition, planting three plants per hole seems promising for improving branching.
\end{abstract}

Keywords: Brazil / Amazon / camu-camu / Myrciaria dubia / crop management / fruiting / plant growth form / pruning

Résumé - Un plus grand nombre de branches permet-il d'améliorer le potentiel de production fruitière du camucamu? Expérimentation de différents types de plantation et de gestion des cultures. Introduction. Pour être plus productives en fruits les branches du camucamu doivent partir de la base de la plante. L'objectif de cette étude était d'examiner comment la croissance des plantes et le rendement en fruits variaient selon le type de plantation et le système de gestion des cultures. Matériel et méthodes. Les paramètres de croissance de la couronne et de production de fruits ont été observés dans des plantations issues de plants bouturés, greffés ou de semis; et dans la plantation issue de plants de semis, les effets de la fertilisation, de la taille et de la densité de peuplement ont été comparés. Résultats et discussion. Les plantes issues de bouturage ont formé plus de branches que celles provenant de greffage, indépendamment de l'origine du greffon. Dans les plantations issues de semis, l'absence de fertilisation et la taille n'ont eu aucun effet sur la formation de branches basales, bien que la taille a retardé la production de fruits. Les plantations avec trois plants par trou ont produit un nombre de branches basales significativement plus grand, mais une analyse plus approfondie de l'effet de ce traitement sur la production de fruits est nécessaire. Conclusion. Utiliser des plants bouturés est techniquement plus souhaitable que des plants greffés pour une meilleure ramification basale des camucamu. Dans les plantations issues de semis, la sélection des plantes pour leur ramification basale abondante est techniquement envisageable. De plus, implanter trois plants par trou s'est avéré une pratique prometteuse qui améliore la ramification.

Mots clés : Brésil / Amazonie / camucamu / Myrciaria dubia / gestion des cultures / fructification / taille de formation des arbres

^ Corresponding author: fedormath@hotmail.com 


\section{Introduction}

Camu-camu (Myrciaria dubia (Kunth) McVaugh, family Myrtaceae) is a shrub native to the Amazonian floodplain. It has aroused scientific and commercial interest due to the high ascorbic acid content of its fruit pulp, which ranges from 0.8

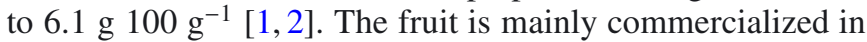
Europe, Japan and the United States, as a source of vitamin C, and in cosmetic and pharmacological products $[3,4]$.

In Peru, camu-camu is usually planted in floodplains of white-water rivers, known locally as restingas [5] and as várzea in Brazilian Amazonia [6]. This is due to the high resistance of the species to flooding and an ability to be grown alongside other temporary crops such as manioc and maize, as well as the natural fertility of the floodplain area itself. Camu-camu farmers in Peru are generally low-income rural subsistence agriculturalists, who own their own seed plantation, and have an average planting area of half a hectare per family [7]. However, in Brazil, camu-camu has been easily adapted to cultivation on Amazonian non-flooding upland land. Growing camu-camu on non-flooded upland soils allows continuous crop production and improved management when compared with floodplain cropping, where fruit production coincides with seasonal pulses of inundation. Under such circumstances fruit often has to be harvested while still green, a stage at which the ascorbic acid content is lower [8].

When grown from seed camu-camu plants display variability across several commercially important morphological traits. Among these, the crown shape is an important characteristic, since this is directly related to fruit yield $[9,10]$. Mature camu-camu trees reach from two up to eight meters in height. Camu-camu can branch from the base, and give rise to a variety of secondary branching patterns $[10,12]$. Of these, cup-shaped ones (single-stemmed with many secondary branches) or glass-shaped (multi-stemmed with many secondary branches) are best for high fruit yield (figure 1) [10].

When increasing the domestication of camu-camu it is key to select morphological characteristics that increase fruit productivity [11], the most important of which is abundant basal branching $[5,10,12]$. Therefore, it is desirable to select seeds from multiple-stemmed plants that have high fruit yield, and have this form of basal branching [10]. However, cultivation of camu-camu is recent (it began in 1996) and originally seeds from wild populations were used, generating high genetic variability within plantings. Nowadays, seeds are sourced from small farmers and research orchards [5,7]. This means that camu-camu production has reached the level known as incipient domestication [13]. Alongside the selective use of camucamu plants with abundant basal branching $[5,10]$, some practical agronomic practices are recommended to stimulate good branching and increase camu-camu fruit production. These include pruning [14], and controlled planting density [10,14]. The pruning method used with Psidium guajava (Myrtaceae), that results in three to four secondary branches some $40-50 \mathrm{~cm}$ from the ground [15], is also the ideal in camu-camu [10]. Moreover, in Psidium guajava it is common to use high planting densities to obtain high yields per area [16]. In camucamu, Pinedo [5] recommends initial planting densities of 3,000 plants $\mathrm{ha}^{-1}$ to promote high yields. However, Yuyama and Valente [10] go further, recommending 4 seedlings per hole $\left(4,000\right.$ plants $\left.\mathrm{ha}^{-1}\right)$, and that branches be heavily pruned and the removal of plants with undesirable features such as a "non-ideal pattern" (figure 1A).

Camu-camu stem diameter is positively related to the branching extent and fruit yield. Fruiting in camu-camu plants begins when the basal stem diameter reaches $2 \mathrm{~cm}$ [9]. During initial growth, camu-camu exhibits strong requirements for nitrogen and organic matter. However, lack of fertilization can cause temporary breaks in apical dominance, stimulating the growth of secondary branches [17].

Cloning camu-camu through cuttings or grafting would allow easy propagation and commercial introduction of desirable agronomic traits. Plants grown from camu-camu cuttings have more than one stalk and plenty of basal, secondary branches. Another option is to use plants grown from cleft grafting, a practice already established in Peru [7]. Cultivation of grafting with more than one bud on a cleft could facilitate branching [11]. However, the behavior of plants grown from grafting varies according to the source of the tissue: branches grafted when young may grow faster and yet take longer to fruit than those grafted when mature [18]. Nevertheless, there are currently no long-term studies on the development of camu-camu clones in Brazil and Peru.

In this context, the current study aimed to compare the effects of different types of planting material originating from seedling, cutting or grafting; and the effect of the cropping management of a seed plantation on crown growth and fruit yield in camu-camu.

\section{Materials and methods}

\subsection{Description of the study site}

An experimental plantation was set up on non-flooded upland soil near the township of Manaquiri $\left(03^{\circ} 25^{\prime} 41^{\prime \prime} \mathrm{S}\right.$ and $\left.60^{\circ} 27^{\prime} 34^{\prime \prime} \mathrm{W}\right), 150 \mathrm{~km}$ from the city of Manaus, State of Amazonas, Brazil. The area was a former cow pasture, and had not been artificially fertilized for some 20 years. An area of $2,000 \mathrm{~m}^{2}$ was plowed and raked to eliminate undesirable plants. The region has a humid equatorial climate, with a mild short dry season (July-September, rainfall of 50-100 mm per month), and a dry-wet transition month (October). The wet season extends from November to May (200-300 mm rainfall monthly). The mean annual temperature is $27^{\circ} \mathrm{C}$ [19].

\subsection{Experimental design}

The first trial aimed to compare the effects of the type of plantation: (a) control, (b) basal grafting, (c) apical grafting, and (d) cutting. The second trial aimed to compare different crop management systems following seed planting: (i/a) control, (ii) zero fertilization, (iii) pruning, (iv) two plants per hole, and (v) three plants per hole. The control treatment was used in both assays for analysis (table I). The experimental design used randomized blocks, with 8 treatments (table I), each treatment with five replicates. Each lot was made up of 5 plants. Spacing was $5 \mathrm{~m}$ between rows and $2 \mathrm{~m}$ between plants. 


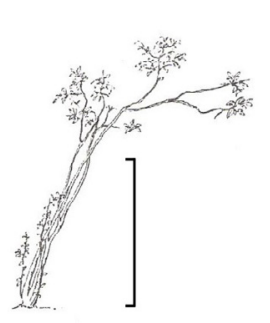

A
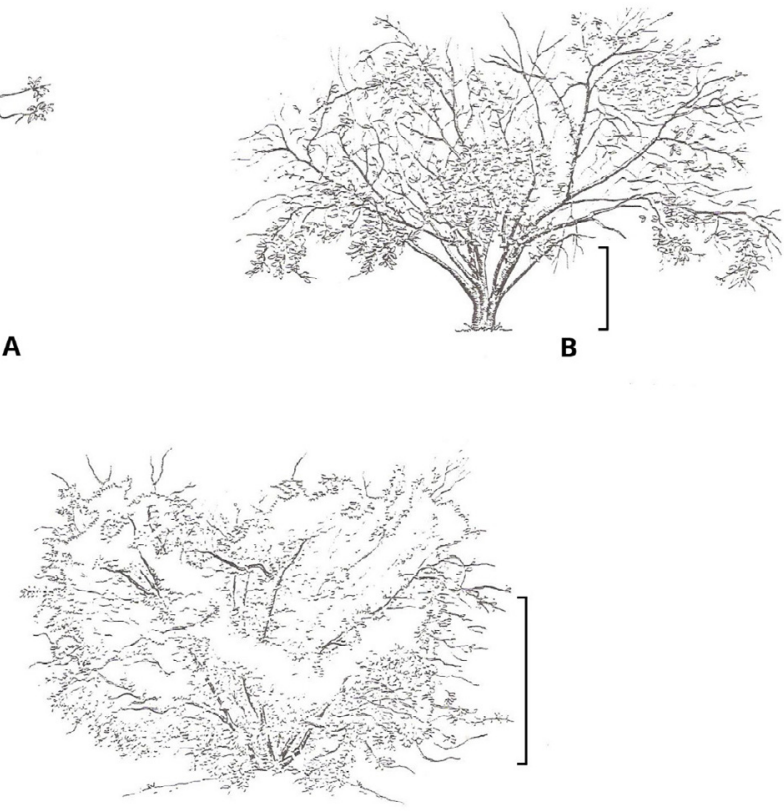

C

Figure 1. Non-ideal (A) and ideal patterns (B and C) of Myrciaria dubia plant growth form. Scale: $50 \mathrm{~cm} \mathrm{for} \mathrm{B;} 1 \mathrm{~m}$ for A and C. Source: Yuyama and Valente [10].

Table I. Initial vegetative description under different types of plantation and crop management in camu-camu (August 2012). Values are the means of five replicates $(n=5)$ of five plants each.

\begin{tabular}{|c|c|c|c|c|}
\hline \multirow{2}{*}{ Trials } & \multirow{2}{*}{ Description } & \multicolumn{3}{|c|}{ Vegetative parameters $^{\mathrm{y}}$} \\
\hline & & $\begin{array}{c}\text { Plant } \\
\text { height }(\mathrm{cm})\end{array}$ & $\begin{array}{c}\text { Stem } \\
\text { diameter }(\mathrm{mm})\end{array}$ & $\begin{array}{l}\text { Branch } \\
\text { number }\end{array}$ \\
\hline \multicolumn{5}{|l|}{ Types of plantation } \\
\hline Control $^{\mathrm{z}}$ & 1 seedling per hole -1 fertilization -0 pruning & $83 \mathrm{ab}$ & $7 \mathrm{~b}$ & $3 \mathrm{a}$ \\
\hline Basal grafting & $\begin{array}{l}1 \text { graft-derived plant per hole originating } \\
\text { from offshoot scion - } 1 \text { fertilization - } 0 \text { pruning }\end{array}$ & $48 \mathrm{c}$ & $7 \mathrm{~b}$ & $3 \mathrm{a}$ \\
\hline Apical grafting & $\begin{array}{l}1 \text { graft-derived plant per hole originating } \\
\text { from canopy scion - } 1 \text { fertilization - } 0 \text { pruning }\end{array}$ & $42 \mathrm{c}$ & $6 \mathrm{~b}$ & $2 \mathrm{a}$ \\
\hline Cutting & $\begin{array}{l}1 \text { cutting-derived plant } \\
\text { per hole - } 1 \text { fertilization - } 0 \text { pruning }\end{array}$ & $66 \mathrm{bc}$ & $10 \mathrm{a}$ & $3 a$ \\
\hline \multicolumn{5}{|c|}{ Crop management in seedling plantation } \\
\hline Control $^{\mathrm{z}}$ & 1 plant per hole -1 fertilization - 0 pruning & $83 \mathrm{ab}$ & $7 \mathrm{~b}$ & $3 \mathrm{~b}$ \\
\hline Unfertilized & 1 plant per hole -0 fertilization -0 pruning & $104 \mathrm{a}$ & $9 \mathrm{ab}$ & $3 \mathrm{~b}$ \\
\hline Pruning & 1 plant per hole - 1 fertilization - 1 pruning & $52 \mathrm{c}$ & $6 \mathrm{~b}$ & $4 \mathrm{ab}$ \\
\hline Two plants per hole & 2 plants per hole -1 fertilization - 0 pruning & $70 \mathrm{bc}$ & $5 \mathrm{~b}$ & $4 a b$ \\
\hline Three plants per hole & 3 plants per hole -1 fertilization - 0 pruning & $70 \mathrm{bc}$ & $6 \mathrm{~b}$ & $6 \mathrm{a}$ \\
\hline
\end{tabular}

${ }^{y}$ Different letters within a column indicate significant differences (Tuke's test, $P<0.05$ ). ${ }^{\mathrm{z}}$ Control: group control for both trials.

\subsection{Sapling production and plantation}

The vegetative propagules and seeds came from a camucamu plantation on non-flooded upland land within the township of Rio Preto, $100 \mathrm{~km}$ from the city of Manaus, State of Amazonas, Brazil. Plant selection was based on the presence of abundant secondary branching from the base to $50 \mathrm{~cm}$ above the ground.

Camu-camu saplings were planted in February 2012, and grown in 2-L plastic bags, using 30-cm-deep Oxisol as a substrate (table I). All saplings were fertilized at planting with
$1 \mathrm{~kg}$ dolomitic limestone, $35 \mathrm{~g}$ urea $(\mathrm{N}), 35 \mathrm{~g}$ triple superphosphate $(\mathrm{P})$ and $23 \mathrm{~g}$ potassium chloride $(\mathrm{K})$, and then sidedressed with NK in May and July 2012. Cover fertilization with NK plus $0.5 \mathrm{~L}$ per sapling of laying chicken manure was repeated every two months from December 2012 to June 2013 and December 2013 to June 2014. Fertilization with P was a single dose in December 2012 and 2014. The fertilizer was applied 20 to $60 \mathrm{~cm}$ from the stem base, forming a circle around each individual plant. The radius of this circle paralleled that of each sapling crown. 
Table II. Crown description and fruit yield under different types of plantation and crop management at 30 months of age. Values are the means of five replicates $(n=5)$ of five plants each.

\begin{tabular}{|c|c|c|c|c|c|c|}
\hline \multirow{2}{*}{ Trials } & \multicolumn{4}{|c|}{ Crown description $^{y}$} & \multicolumn{2}{|c|}{ Fruit yield ${ }^{y}$} \\
\hline & $\begin{array}{l}\text { Branch } \\
\text { number }\end{array}$ & $\begin{array}{c}\text { Plant } \\
\text { height }(\mathrm{cm})\end{array}$ & $\begin{array}{c}\text { Stem } \\
\text { diameter }(\mathrm{mm})\end{array}$ & $\begin{array}{c}\text { Crown shadowing } \\
\text { area }\left(\mathrm{cm}^{2}\right)\end{array}$ & $\begin{array}{l}\text { Fruit yield } \\
\left(\mathrm{kg} \mathrm{ha}^{-1}\right)\end{array}$ & $\begin{array}{c}\text { Plants bearing } \\
\text { fruits }(\%)\end{array}$ \\
\hline \multicolumn{7}{|c|}{ Different types of plantation } \\
\hline Basal grafting & $4 \mathrm{~b}$ & $222 \mathrm{~b}$ & $31 \mathrm{ab}$ & $7,123 \mathrm{a}$ & $144 \mathrm{a}$ & $87 \mathrm{a}$ \\
\hline Apical grafting & $3 \mathrm{~b}$ & $213 \mathrm{~b}$ & $31 \mathrm{ab}$ & $4,777 \mathrm{a}$ & $150 \mathrm{a}$ & $87 \mathrm{a}$ \\
\hline Cutting & $9 \mathrm{a}$ & $227 \mathrm{ab}$ & $33 \mathrm{a}$ & $4,605 \mathrm{a}$ & $208 \mathrm{a}$ & $80 \mathrm{a}$ \\
\hline Control $^{z}$ & $10 \mathrm{bc}$ & $252 \mathrm{ab}$ & $24 \mathrm{ab}$ & $6,770 \mathrm{a}$ & $18 \mathrm{ab}$ & $32 \mathrm{ab}$ \\
\hline Unfertilized & $12 \mathrm{ab}$ & $239 a b$ & $21 \mathrm{~b}$ & $6,635 \mathrm{a}$ & $63 \mathrm{a}$ & $40 \mathrm{a}$ \\
\hline Pruning & $7 \mathrm{c}$ & $261 \mathrm{a}$ & $25 \mathrm{ab}$ & $3,919 \mathrm{a}$ & $0 \mathrm{~b}$ & $0 \mathrm{c}$ \\
\hline Two plants per hole & $13 \mathrm{ab}$ & $228 \mathrm{~b}$ & $26 \mathrm{a}$ & $4,428 \mathrm{a}$ & $25 \mathrm{ab}$ & $52 \mathrm{a}$ \\
\hline Three plants per hole & $14 \mathrm{a}$ & $247 \mathrm{ab}$ & $29 \mathrm{a}$ & $6,600 \mathrm{a}$ & $19 a b$ & $40 \mathrm{a}$ \\
\hline
\end{tabular}

${ }^{y}$ Different letters within a column indicate significant differences (Tuke's test, $P<0.05$ ). ${ }^{\mathrm{z}}$ Control: group control for both trials.

Branches for grafting were some $5 \mathrm{~mm}$ wide and $10 \mathrm{~cm}$ long, originating from canopy shoots and offshoots of the stem providing apical and basal type grafts, respectively. The grafting methodology followed Moreira and Ferreira [20].

Every three months it was necessary to eliminate rootstock offshoots. These sprouts arise between the rootstock and scion, and reduce overall grafting quality [18]. Branches for cuttings were around $10 \mathrm{~mm}$ in diameter and $25 \mathrm{~cm}$ in length, and originated from stem offshoots. Cutting propagation followed Pereira's [21] methodology.

Pruning treatment was carried out $20 \mathrm{~cm}$ from the ground one month after planting. A second pruning was performed two months after the first some $50 \mathrm{~cm}$ from the ground, following the recommendations of Pinedo et al. [14].

\subsection{Data collection}

The following traits were measured: plant height from the base to the top of the crown; main stem diameter $10 \mathrm{~cm}$ from the ground (in cuttings, measured on the cutting, and on the graft measured on the rootstock); number of basal branches exceeding $50 \mathrm{~cm}$ in length, and sprouting at heights up to $50 \mathrm{~cm}$ from the ground; and crown shadowing area, calculation based on the ellipse area formula:

\section{Crown shadowing area $=(\pi a b) / 4$}

where $a$ represents the length of the largest diameter, and $b$ corresponds to the length of the smallest diameter). These measurements were taken during May 2014 in plantations operating under a variety of planting schemes and cropping management formats. In all types of plantations, measurements were taken every three months, between August 2012 and May 2014. During these periods, the quarterly relative growth rate (RGR) was determined between two consecutive measurements [22]: plant height and basal branch number. In addition, the number of plants bearing fruits (percentile) and fruit yield were measured from May 2013 to May 2014. The data percentage was the arcsine of the square root-transformed $(\mathrm{x}+0.5)[22]$.

\subsection{Data analysis}

For data analysis, the two trials were considered separately. For both trials, all data were submitted to an analysis of variance (ANOVA, $P<0.05$ ). The treatment means were analyzed with Tukey's test at $P=0.05$ [22].

\section{Results and discussion}

\subsection{Different types of plantation}

On average, plants derived from cuttings produced about three times the number of basal branches than those derived from grafts [9.0 vs. 3.3]. The difference was statistically significant. Therefore, plantations originating from cuttings are more suitable for camu-camu commercialization than those derived from grafts.

Cutting and seed plantations produced a similar number of basal branches, but cutting plantations produced fruit more quickly and had double the fruit production of seed plantings (table II). Seed-derived plants sprouted more extensively from the base of the plant than those derived from cuttings, but they did not have as uniform a development as cutting-derived individuals: this was probably more influenced by the growth than the stem diameter, which was greater in plants derived from cuttings than those originating from seedlings (table II). The levels of fruit production in this study (80\% of plants fruiting) differ from that of Pinedo [5], who reported 19\% fruiting for two-year-old camu-camu plants grown from cuttings planted in floodplain ecosystems. Lack of fertilizer and seasonality of crop production in floodplain camu-camu are probably responsible for such small crop volumes. In contrast, in non-flooded uplands [6], camu-camu can be better managed and produce fruit continuously [8].

Our findings show that plants grown from cuttings have similar fruiting rates and fruit yields to those derived from apical and basal grafts. However, this could vary over time, as plants derived from cuttings formed a greater number of basal branches and so could eventually exceed the fruit production of those derived from grafts (table II). Comparing the 


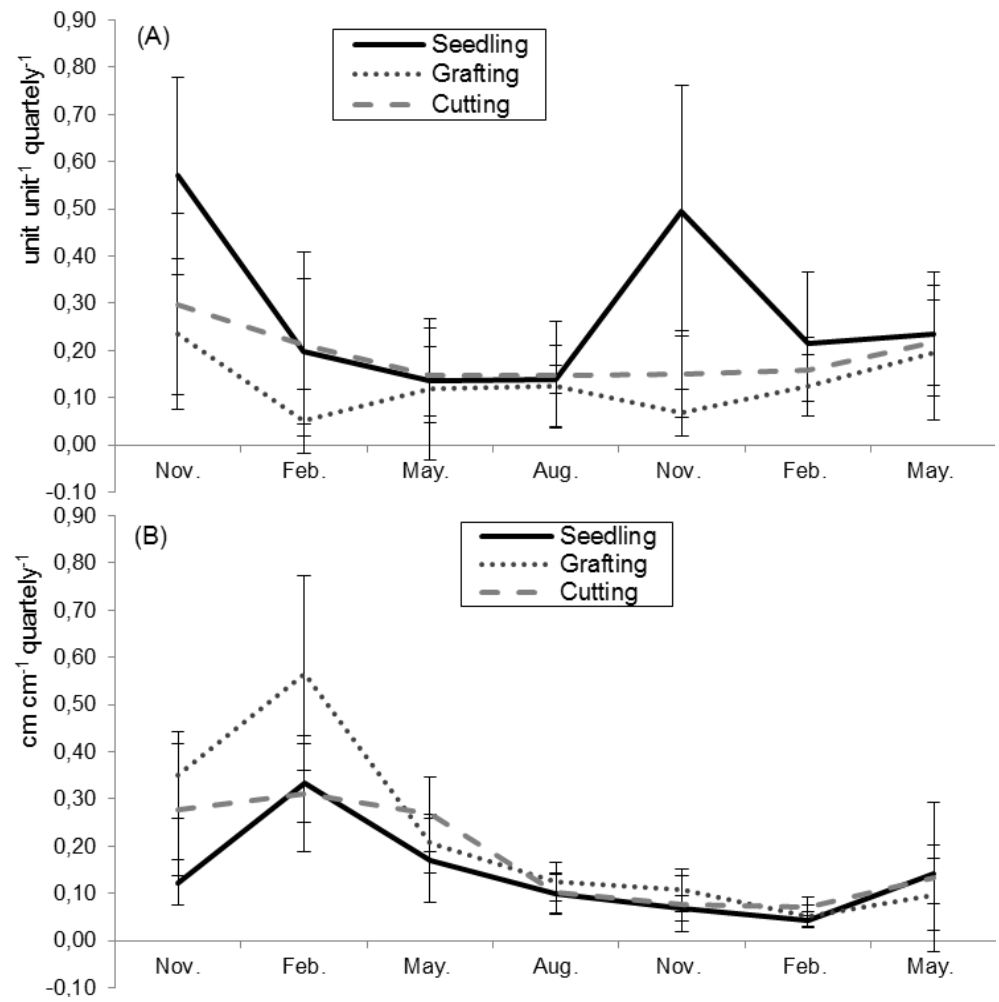

Figure 2. Relative vegetative growth rate (RGR) under three propagation methods (November 2012-May 2014). (A) Basal branch number; (B) Plant height. Values represent means and standard deviations of five replicates $(n=5)$ of five plants each.

two vegetative propagation techniques, plants grown from cuttings would be recommended for the promotion of camu-camu planting, since they are easier and less expensive to produce in a plant nursery. Camu-camu plants grown from cuttings take three months to produce [21], versus the 12 months it takes to produce them by grafting [20]. Furthermore, the present study found it necessary to eliminate lateral sprouts from the graft rootstocks every three months, which would also increase management costs [10].

Grafts showed no significant difference in the formation of basal branches, regardless of scion origin (apical or basal). In this, our results differ from those of Harmann et al. [18], who suggested that growth of vegetative progeny can vary according to the position of the vegetative propagules from the donor plant (basal or apical shoots). However, in the nursery, we found that grafts of basal shoots had better success propagating than apical shoots (90\% vs. 50\% of grafted saplings), suggesting the first technique could work better with grafts.

During our study, the relative height of growth and peaks of seedling growth coincided with the rainy season (DecemberMay). Conversely, the number of secondary branches was greater in the dry season (June-November) (figure 2). This result is in agreement with the phenology of Eugenia stipitata, which also exhibits higher vegetative growth during the rainy season than in the dry [25]. The result supports the hypothesis that apical dominance may be temporarily broken by water stress, encouraging the growth of secondary branches [17]. Conversely, grafts branch more in the rainy season (figure 2). This suggests that the rootstock exerted apical dominance on the scion during the period of water stress (dry season). There- fore, pruning of shoots derived from rootstock should be intensified in the dry season to prevent it weakening the graft.

Cutting-derived plants have basal branch growth rates lower than those from seed-derived plants (figure 2). However, at the end of the current study, the diameter of the main stem was statistically larger in plants derived from cuttings than those grown from seeds (table II). Probably, the secondary branches of plants from cuttings grow more homogeneously, reflecting a greater increase in the stem base than in seedlings.

\subsection{Crop management in seed planting}

Pruning and the absence of fertilization had no significant effect on the formation of basal branches in camu-camu plantations. This result is consistent with the hypothesis that restricting nutrients is not a major mechanism for the growth of branches [17]. On the other hand, this result contradicts the hypothesis that pruning increases the number of branches in early-stage camu-camu plantations [5]. In our experiment, pruning reduced fruiting (table II). Similar findings were reported by Serrano et al. [24] with pruned Psidium guajava cuttings, where branching, the percentage of fruit set and fruit production were affected in relation to the distance of pruning from the plant base. Clearly, pruning at the beginning of the planting in camu-camu is not necessary. Therefore, selection of plants showing abundant branching from the base is a promising technique for obtaining good branching [10].

Plantations with three plants per hole had a significantly greater number of basal branches (table I), but further evaluation is necessary to analyze the effect of this treatment on fruit production. The three-per-hole density $\left(3,000\right.$ plant ha $\left.^{-1}\right)$ is 
greater than usually recommended for seedlings of camu-camu in Peru $\left(1,111\right.$ plants ha $\left.{ }^{-1}\right)$. However, the distance used in our study is greater $(5 \times 2 \mathrm{~m} v s .3 \times 3 \mathrm{~m})$. Therefore, the distance and the density used in our study are equivalent to those recommended when planting camu-camu seedlings. Small-scale camu-camu farmers in Peru prefer wider spacing ( 4 or $5 \mathrm{~m}$ between trees), since they wish to intercrop camu-camu with staple food crops such as cassava (Manihot esculenta) and maize (Zea mays) for home consumption or sale, for periods longer than three years [7].

\section{Conclusion}

For setting up a camu-camu plantation, plants derived from cuttings are technically more appreciated than those derived from grafts, because they have better branching development. However, management techniques to increase the branches in grafting are an important yield-determining factor.

In seed-derived plants, pruning and lack of nutrients are not necessary to stimulate branching. However, efficient methods of selection are necessary to ensure these features remain stable.

The use of three plants per hole increases the number of branches by $10 \mathrm{~m}^{2}$, but more than one assessment is required to fully understand the effects on fruit production and should form the basis of future research.

Acknowledgements. The authors would like to thank the graduate program in Botany of the National Institute of Amazonian Research - INPA. This work was financially supported by the CNPq (National Council for Scientific and Technological Development), Brazil. The authors are grateful to Adrian Barnett for help with the English. Maria de Fátima Vieira Nowak received a grant from the "Fondo de Amparo da Pesquisa da Amazônia - FAPEAM" to finish the manuscript. Charles Roland Clement is acknowledged for the mentoring throughout the research work.

\section{References}

[1] Zapata S.M., Dufour J.P., Camu-camu Myrciaria dubia (H.B.K.) McVaugh: Chemical composition of fruit, J. Sci. Food Agric. 61 (1993) 349-351.

[2] Yuyama K., Aguiar J.P.L., Yuyama L.K.O., Camu-camu: um fruto fantástico como fonte de vitamina C, Acta Amazonica 32(2002) 169-174.

[3] PROMPERU, Exportación del camu-camu según sus principales mercados y Principales presentaciones, 2013, Peru, http://www.siicex.gob.pe/siicex/apb/ReporteProducto.aspx? psector $=1025 \&$ preporte $=$ prodmerc \&pvalor $=1920$.

[4] Sabbe S., Van Damme P.,Verbeke W., European market environment for selected Latin American tropical fruit species, Acta Hortic. 975 (2013).

[5] Pinedo P.M., Camu-camu (Myrciaria dubia, Myrtaceae). Aportes para su aprovechamiento sostenible en la Amazonía peruana, Instituto de Investigaciones de la Amazonía Peruana, Iquitos, Peru, 2011.

[6] Junk W.J., Piedade M.T.F., Schöngart J., Cohn-Haft M., Adeney M., Wittmann F., A classification of major naturally-occurring Amazonian lowland wetlands, Wetlands, 31 (2011) 623-640.
[7] Penn J.W.JR., The cultivation of camu-camu (Myrciaria dubia): A tree planting programme in the Peruvian amazon. For. Trees Livelihoods 16 (2006) 85-101.

[8] Yuyama K., A cultura de camu-camu no Brasil, Rev. Bras. Frutic. 33 (2011) 335-690.

[9] Oliva C.C., Evaluación de la productividad del camu-camu Myrciaria dubia (H.B.K) Mc Vauhg en Loreto. Universidad nacional de la Amazonía Peruana, Iquitos, Peru, Monograph, 2002, $120 \mathrm{p}$.

[10] Yuyama K., Valente J.P., Camu-camu (Myrciaria dubia (Kunth) Mac Vaugh), CRV, Curitiba, Brasil, 2011.

[11] Borem A. Melhoramentos de Plantas. UFV, Viçosa, Brasil, 2001.

[12] Bacelar-Lima Ch.G. Estudos da biologia reprodutiva, morfologia e polinização aplicadosà produção de frutos de camu-camu (Myrciaria dubia) adaptadas à terra firme da Amazônia Central, Brasil. Instituto Nacional de Pesquisas da Amazônia, Manaus, Brazil, Thesis, 2009, $121 \mathrm{p}$.

[13] Clement C.R., 2001. Melhoramento de espécies nativas, In: Nass L.L., Valois A.C.C., Melo I.S., Valadares-Inglis M.C. (Eds.), Recursos genéticos E melhoramento - plantas, Fundação de Apoio à Pesquisa Agropecuária de Mato Grosso, Fundação MT, Rondonópolis, MT, Brazil, 2001.

[14] Pinedo P.M., Riva R.R., Rengifo S.E., Delgado V.C., Villacrés V.J., González C.A., Inga S.H., López U.A., Farroñay P.R., Vega V.R., Linares B.C 2001. Sistema de producción de camu-camu en restinga. Instituto de Investigación de la Amazonía PeruanaIIAP, Iquitos, Perú, 2001.

[15] Penteado S.R., Enxertia e poda de fruteiras: como fazer enxertar, fazer mudas e podar as fruteiras, Via Orgânica, Vila Faustino, São Paulo, Brazil, 2010.

[16] Kundu S. Effect of high density planting on growth, flowering and fruiting of guava (Psidium guajava L.). Acta Hortic. 735 (2007) 267-270.

[17] Brayton F.W., Apical control of branch growth and angle in woody plants, Am. J. Bot. 87 (2000) 601-607.

[18] Hartmann H.T., Kester D.E., Davies Junior F.T., Genive R.L., Plant propagation: principles and practices, Prentice Hall, New Jersey, USA 2002.

[19] Fisch G., Marenco J.A., Nobre C.A. Uma revisão geral sobre o clima da Amazônia. Acta Amazonica 28 (1998) 101-126.

[20] Moreira Filho M., Ferreira Do N.S.A., Clonagem do camucamu arbustivo em porta-enxertos de camu-camu arbustivo e arbóreo, Rev. Bras. Frutic. 31(2009) 1202-1205.

[21] Pereira B.G., Produção de mudas de camu-camu (Myrciaria dubia H.B.K.) McVaugh) por estaquia utilizando ramos provenientes de diferentes tipos e posição da planta, Universidade Federal do Amazonas, Manaus, Brazil, Monograph, 2002, $53 \mathrm{p}$.

[22] Gotelli N.J., Ellison, A.M., Princípios de estatística em ecologia, Armed Editora S.A, Posto Alegre, Brasil, 2011.

[23] El-Siddig K., Ludders P., Ebert G., Adiku S.G.K. Response of rose apple (Eugenia jambos L.) to Water and nitrogen supply. J. Appl. Bot. 72 (1998) 203-206.

[24] Serrano L. A. L., Martins M. V. V., Lima I. M., Marinho C. S., Tardin F.D. Épocas e intensidades de poda de frutificação na goiabeira ' Paluma', Ver. Rev. Bras. Frutic. 30 (2008) 994-1000.

[25] Van Kanten R., Beer J.,Production and phenology of the shrub Eugenia stipitata in agroforestry systems in Costa Rica, Agrofor. Syst. 64 (2005) 203-209. 